\title{
The Effect of Nutrition Education on Nutrition Knowledge and Macronutrition Intake in Muay Thai Athletes
}

\author{
Maryati Dewi, Gina Hanifah, Asep Iwan Purnawan, Witri Priawanti Putri, Gurid Pramintarto Eko Mulyo* \\ Department of Nutrition, Health Polytechnic, Ministry of Health, Bandung, Indonesia
}

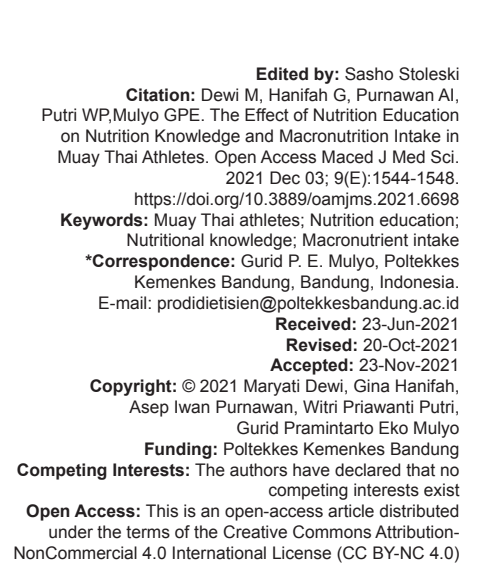

\begin{abstract}
BACKGROUND: Athletes' achievements require the support of sports science and technology. One of the supporting sciences is sports nutrition services by fulfilling athlete nutrition through foodservice and nutrition education in nutrition counseling or nutrition counseling according to the needs and conditions of athletes.

AIM: This study aims to determine the effect of nutrition education on nutritional knowledge and macronutrient intake in Muay Thai athletes in Cimahi city.

METHODS: This type of research is a Quasi experiment by applying a one group pre- and post-test design: Nutrition education using leaflets. The sample is Muay Thai athletes in Cimahi city who are actively practicing at the Empire Muaythai Camp as many as ten people. Data were collected by filling in the respondent's characteristics, knowledge of nutrition, and intake of macronutrients.

RESULTS: Based on the Wilcoxon test, it was found that there was an effect of providing nutrition education using leaflets on nutritional knowledge $(p=0.005)$ and protein intake $(p=0.047)$.

CONCLUSION: It is recommended that regular and periodic nutrition education be given to athletes and coaches as well as collaborate with nutritionists regarding nutritional fulfillment for athletes to increase macronutrient intake so that the performance of Muay Thai athletes in Cimahi city is optimal.
\end{abstract}

\section{Introduction}

Sport is a form of physical activity carried out in a structured, planned, and continuous manner by following specific rules and improving physical fitness and achievement [1]. Muay Thai, translated into English as Thai Boxing, is Thailand's national sport and is a martial art with its origins in the Siamese or Thai army [2].

Non-technical factors and technical factors influence the performance of an athlete. Non-technical factors include the policies implemented, the management methods used to improve athlete performance, available human resources, available funding, the organization responsible for implementing procedures, and wellplanned and scheduled programs. Simultaneously, technical factors include health factors, fitness level, food intake, psychological condition, hydration status, physical activity, facilities, and infrastructure support [1]. Nutritional intake needed by athletes consists of macronutrients and micronutrients. The macronutrient group includes carbohydrates, fats, and proteins, while micronutrients are vitamins and minerals. The macronutrient group is a producer of energy for the body needed to carry out various activities. The energy and nutrient content in an athlete's diet is very much needed [3].
Food intake in the form of macronutrient intake can affect an athlete's performance when competing. Suppose an athlete's food intake is not fulfilled or insufficient. It will result in the athlete becoming weak and quickly experiencing fatigue so that the athlete's performance is not optimal, and performance decreases. Meanwhile, if the athlete's food intake is fulfilled, the athlete is not prone to fatigue, so that the athlete's performance is maximal, and the athlete will excel [1].

Nutrition is recognized as a key component of optimal sports performance, with the science and practice of sports nutrition evolving rapidly [4]. In research conducted by Hansen et al., in 2014, it was found that a scientifically planned nutrition strategy (consisting of fluids, carbohydrates, sodium, and caffeine) can help non-elite runners complete marathons faster than self-selected nutrition strategies [5] and trained cyclists complete time trials faster [6]. This achievement requires support in the form of sports science and technology. According to the athletes' needs and conditions, one of the science supports is achieving sports nutrition services by fulfilling athlete nutrition through food management and nutrition education in nutritional counseling or nutrition counseling according to the athletes' needs and conditions [1].

Research Puspaningtyas et al. (2019) stated that nutrition education in the form of one-time nutrition 
education could increase soccer athletes' knowledge about balanced nutrition [7].

Research conducted by Thasim et al. (2013) showed that the provision of nutritional education affected increasing children's knowledge of overnutrition $(p=0.000)$ and had an effect on changes in protein intake $(p=0.018)$ and fat intake $(p=0.002)$ [8]. Another research conducted by Ramadhanti et al. (2019) said that providing nutrition education in nutrition education using leaflet media could increase the respondent's knowledge [9]. Researchers are interested in analyzing nutrition education on nutritional knowledge and macronutrients to Muay Thai athletes in Cimahi city to achieve optimal performance and performance.

\section{Methods}

This study's research design was a quasiexperimental one-group pre-test and post-test. The independent variable was nutrition education using leaflet media, and the dependent variable nutritional knowledge and macronutrient intake. Is to determine the effect of nutrition education? Conduct this research from January 2020 to April 2020 at one of the sports training centers in Cimahi.

The nutrition education carried out was regarding the intake and regulation of food for athletes, which was carried out 3 times with an interval of 3 days through nutrition education using the lecture method with leaflet media. The population in this study was ten athletes of Cimahi city Muay Thai who were actively exercising. The sample in this study was all Muay Thai athletes who were members of the population as many as ten people.

The data collected are primary data, including respondent characteristics data, nutritional knowledge data obtained through filling out a knowledge questionnaire of 20 questions, and macronutrient intake data are obtained based on the results of 24-h multiple recalls measured on weekdays and holidays (weekends). This study uses informed consent that has been approved and signed by the respondent. This research has been declared ethical following the seven 2011 WHO Standards, with No. 20/KEPK/EC/II/2020.

\section{Results}

\section{Nutrition knowledge}

The respondent's nutritional knowledge is obtained based on the number of correct answers divided by the number of questions multiplied by 100 to get the healthy knowledge score of each athlete.
Table 1 shows the average pre- and postintervention; there is an increase in the knowledge score of 24 points.

Table 1: Pre- and post-knowledge score of nutrition education for Muay Thai athletes in Cimahi city

\begin{tabular}{lllll}
\hline Knowledge score & Min & Max & Average & SD \\
\hline Pre-test & 40 & 80 & 57 & 12.52 \\
Post-test & 75 & 90 & 81 & 5.16 \\
\hline
\end{tabular}

\section{Macronutrient intake}

Macronutrient intake was obtained from the 24-h recall. The 24-h recall interviews were conducted before and after the intervention. The results will be compared with the needs of each athlete to determine whether the athlete's macronutrient intake is met or not.

Based on Table 2 regarding the intake of macronutrients in Muay Thai athletes in Cimahi city, both before the intervention or after the intervention, it is known that carbohydrate intake is $65 \%$ of the need, fat intake is $45.8 \%$ of the condition, and protein intake is $38.8 \%$ of the state. Hence, macronutrients in Muay Thai athletes in Cimahi city are $100 \%$ still below the suitable needs.

Table 2: Macronutrient intake before and after nutrition education for Muay Thai

\begin{tabular}{llll}
\hline Variable & Before the intervention & After the intervention & Fulfillment \\
\hline Carbohydrate intake & & & \\
Average & 226 & 252 & $65 \%$ \\
$\quad$ Std. Deviation & 53.10 & 35.89 & \\
$\quad$ Minimum & 145 & 206 & \\
$\quad$ Maximum & 295 & 295 & \\
Fat intake & & & $45.8 \%$ \\
Average & 41 & 87 & \\
$\quad$ Std. Deviation & 15.79 & 30 & \\
$\quad$ Minimum & 21 & 59 & $38.8 \%$ \\
Maximum & 66 & 60 & \\
Protein intake & & 5.13 & \\
Average & 49 & 54 & \\
Std. Deviation & 13.53 & 70 & \\
Minimum & 30 & & \\
Maximum & 78 & & \\
\hline
\end{tabular}

\section{Statistic test}

The data analysis used to determine the effect of nutrition education using leaflet media on nutritional knowledge and macronutrient intake for Muay Thai athletes in Cimahi city was a non-parametric test, namely, the Wilcoxon test.

Based on Table 3, the Wilcoxon test results in nutrition education on nutritional knowledge and macronutrients in Muay Thai athletes in Cimahi city. The effect of giving nutrition education on nutritional knowledge obtained $p=0.005$ ( $p<0.05)$. It means that there are differences in nutritional knowledge scores before and after nutrition education. Hence, it can be concluded that nutrition education can improve nutritional knowledge in Muay Thai athletes in Cimahi city or provide nutrition education on nutritional knowledge of Muay Thai athletes in Cimahi city. 
Table 3: Statistical test values of change before and after the intervention

\begin{tabular}{|c|c|c|c|c|c|}
\hline \multirow{2}{*}{$\begin{array}{l}\text { Variable } \\
\text { Post-test and pre- test }\end{array}$} & \multirow{2}{*}{$\frac{\mathrm{N}}{\text { Negative ranks }}$} & \multirow{2}{*}{$\begin{array}{l}\text { Mean rank } \\
0\end{array}$} & \multicolumn{2}{|c|}{ Sum of rank } & \multirow{2}{*}{$\begin{array}{l}\mathrm{p} \text {-value } \\
0.005\end{array}$} \\
\hline & & & 0.00 & 0.00 & \\
\hline & Positive ranks & 10 & 5.50 & 55.00 & \\
\hline & Ties & 0 & & & \\
\hline & Total & 10 & & & \\
\hline \multirow{4}{*}{$\begin{array}{l}\text { Carbohydrate intake after } \\
\text { and before intervention }\end{array}$} & Negative ranks & 3 & 5.50 & 16.50 & 0.262 \\
\hline & Positive ranks & 7 & 5.50 & 38.50 & \\
\hline & Ties & 0 & & & \\
\hline & Total & 10 & & & \\
\hline \multirow{4}{*}{$\begin{array}{l}\text { Fat intake after and before } \\
\text { intervention }\end{array}$} & Negative ranks & 3 & 6.00 & 18.00 & 0.333 \\
\hline & Positive ranks & 7 & 5.29 & 37.00 & \\
\hline & Ties & 0 & & & \\
\hline & Total & 10 & & & \\
\hline \multirow{4}{*}{$\begin{array}{l}\text { Protein intake after and } \\
\text { before intervention }\end{array}$} & Negative ranks & 1 & 8.00 & 8.00 & 0.047 \\
\hline & Positive ranks & 9 & 5.22 & 47.00 & \\
\hline & Ties & 0 & & & \\
\hline & Total & 10 & & & \\
\hline
\end{tabular}

In addition, the results obtained from carbohydrate intake with a value of $p=0.262$ $(p>0.05)$, fat intake $p=0.33(p>0.05)$, and protein intake $p=0.047(p<0.05)$. From these results, it is known that providing nutrition education can increase protein intake in Muay Thai athletes in Cimahi city. It can conclude that there is an effect of providing nutrition education on the protein intake of Muay Thai athletes in Cimahi city. While nutrition education on carbohydrate and fat intake cannot increase intake, it can conclude that there is no effect of providing nutrition education on carbohydrate and fat intake in Muay Thai athletes in Cimahi city.

\section{Discussion}

\section{Nutritional knowledge}

The results showed differences in nutritional knowledge among Muay Thai athletes in Cimahi city before and after being given nutrition education using leaflets to increase athlete's nutritional knowledge. Nutritional education has to provide influences changes in an athlete's healthy ability.

Before nutrition education regarding nutritional knowledge for athletes, Muay Thai athletes in Cimahi city can have less healthy knowledge. They have less nutritional expertise because they are not exposed to nutrition from a nutritionist. Athletes get more information from the internet and senior athletes or coaches' experience. Lack of knowledge has led Cimahi city's Muay Thai athletes to be misinformed from untrusted sources.

In line with Andarmoyo's (2015) research, the level of knowledge of tuberculosis (TB) sufferers before being given nutrition education was stated to have insufficient knowledge and had a significant increase after being given nutrition education. It is seen that the provision of nutrition education using leaflet media is effective in increasing knowledge about TB prevention behavior [10].
In the research conducted by Puspaningtyas et al. (2019), nutrition education in nutritional counseling effectively increased athletes' knowledge of balanced nutrition and meeting athletes' fluid needs. The knowledge value of athletes before nutrition education was 56.67. After being given education, there was an increase in knowledge to 75.24 [7]. In the results of this study, the level of understanding of Muay Thai athletes in Cimahi city is included in the category of knowledge, which is defined as remembering previously learned material, including recalling something specific from all the materials studied or stimuli received. This is known from the athlete's energy and macronutrient intake results, which are still below the requirement.

\section{Macronutrient intake}

Table 2 shows the results of measurements of macronutrient intake for Muay Thai athletes in Cimahi city. Based on these results, it is known that the macronutrient intake of Muay Thai athletes in Cimahi city before and after being given intervention in nutrition education, which is $100 \%$, is still below the need. The most of the energy comes from carbohydrates, including carbohydrate food sources in the staple food group [11].

In the body, carbohydrates are metabolized into blood glucose, liver glycogen, and muscle glycogen. All types of carbohydrates consumed are converted into glucose in the body. The formed glucose is store in the bloodstream as blood glucose and an energy reserve in the liver and muscles' glycogen. If an athlete lacks carbohydrate intake, it causes glycogen formation in the liver and muscles to be disturbed [1].

The number of portions causes inadequate fat intake, and the frequency of athletes eating is less so that they cannot meet the athlete's fat needs. Simultaneously, the body's body span is needed for organ function and hormone formation, although it does not directly play a role in increasing performance [1]. The insufficient protein intake proves that the consumption of athlete's side dishes is not good.

Lack of protein intake in athletes can cause interference with the formation of enzymes and antibodies so that the athlete's endurance decreases and gets sick quickly [1]. The research results by Dagan et al. (2015) show that media is influential in increasing knowledge about nutrition, including videos, booklets, pocketbooks, leaflets, internet media, or social media such as Facebook, Twitter, Instagram, and WhatsApp [11].

\section{The effect of nutrition education on nutritional knowledge}

Providing nutrition education through nutrition education using leaflet media to Muay Thai athletes 
in Cimahi city aims to increase knowledge about the importance of fulfilling athletes' nutrition. Muay Thai athletes in Cimahi city have a good understanding. The research results found that the athlete's knowledge score had increased, seen from the pre-test and post-test results. Analysis with the Wilxocon test obtained $p=0.005$ ( $p<0.05)$, which means there are differences in knowledge scores before and after nutrition education is given, it can be concluded that the provision of nutritional education using leaflet media can increase the nutritional knowledge of Muay Thai athletes in Cimahi city or there is the effect of providing nutrition education on a healthy understanding of Muay Thai athletes in Cimahi city.

The results of other research conducted by Rachmawati and Nurafifah (2014) showed the influence of nutrition education on the nutritional knowledge of respondents, as evidenced by the significance value (p) of 0.000 [12].

Having good nutritional knowledge or practice does not directly determine athletic performance. However, nutrition education interventions can improve athlete performance by meeting adequate energy intake, lean muscle mass, and proper weight gain in athletes [13].

\section{The effect of nutrition education on macronutrient intake}

Providing nutrition education using leaflet media to Muay Thai athletes in Cimahi city aims to increase knowledge about the importance of fulfilling nutrition for athletes to Muay Thai athletes' energy intake and macronutrition in Cimahi city are per their needs. Based on the results of the study using the Wilcoxon test analysis, it was found the results of energy intake with a value of $p=0.093(p>0.05)$, carbohydrate intake $p=0.262(p>0.05)$, fat intake $p=0.33(p>0.05)$, and protein intake $p=0.047(p<0.05)$. From these results, it is known that providing nutrition education can increase protein intake in Muay Thai athletes in Cimahi city. It can conclude that there is an effect of providing nutrition education on the protein intake of Muay Thai athletes in Cimahi city. While nutrition education on energy, carbohydrate, and fat intake cannot increase intake, it can conclude that there is no effect of providing nutrition education on energy, carbohydrate, and fat intake in Muay Thai athletes in Cimahi city.

This study is in line with research conducted by Pakhri et al. (2017), that there is an effect of nutrition education on protein intake before and after the intervention with a value of $p=0.002(p<0.05)$ [14]. Another study conducted by Thasim et al. (2013) showed that the provision of nutritional education did not affect changes in energy intake, carbohydrates in overweight children with a value of $p=0.345(p>0.05)$ and weight of $p=0.125$ ( $p>0.05$ ). It means that no difference in carbohydrate intake before and after nutrition education is given [8].
The impact of proper nutrition knowledge for athletes has been shown to improve with nutritional interventions. Nutrition education interventions have an effect on the eating habits and dietary practices of athletes [13]. Athletes who recognize the important role of an adequate diet and reflect knowledge in their dietary behavior and practices are more successful in their sporting life [15].

Sources of nutritional information among athletes are another factor that determines their nutritional knowledge. Most studies report coaches (not nutritionists) as a source of nutritional information for athletes. In addition, the coach may not be qualified to provide these services [16]. Therefore, it is important to provide interventions to provide the impact of adequate and appropriate nutrition education to the athletic team; coaches and coaches of athletes will improve the performance of athletes [17].

\section{Conclusion}

Based on the results of the research that has been done, the results of the statistical test of knowledge indicate that there is a significant effect of providing nutrition education on the nutritional knowledge of Muay Thai athletes in Cimahi city with $p=0.005$. The results of the statistical test of protein intake $p=0.047$ showed a significant effect of nutrition education on protein intake.

It is necessary to provide nutrition education to athletes and coaches regarding the fulfillment of nutrition for athletes on a regular and periodic basis as well as in collaboration with nutritionists to increase the intake of macronutrients so that Muay Thai athletes in Cimahi city have good and optimal performance so that they can compete at a greater level. The media used in providing nutrition education must include examples of daily food portions in household sizes to make it easier for athletes to apply the results of nutrition education.

\section{Acknowledgment}

The author thanks to convey to all parties who have contributed to this research to be carried out well.

\section{References}

1. Menteri kesehatan RI 2014. Menteri Kesehatan RI; 2014 p. 1-2. Available from: https://repositories.lib.utexas.edu/ handle/2152/39127\%0A; https://cris.brighton.ac.uk/ws/ 
portalfiles/portal/4755978/Julius+Ojebode $\% 27 s+$ Thesis. pdf\%0Ausir.salford.ac.uk/29369/1/Angela_Darvill_thesis esubmission.pdf\%0A; https://dspace.lboro.ac.uk/dspace-jspui/ ha [Last accessed on 2021 Jun 20].

2. Muay Thai History World Thai Boxing Association. Available from: https://thaiboxing.com/about/muay-thai-history [Last accessed on 2021 Jun 22].

3. Syafrizar S, Welis W. Sports Nutrition. Malang; Winka Media: 2009.

4. Burke LM, Meyer NL, Pearce J. National nutritional programs for the 2012 London Olympic Games: A systematic approach by three different countries. In: van Loon LJ, Meeusen R, editors. Limits of Human Endurance. Vol. 76. Vevey, Switzerland: Nestle Nutrition Institute Workshop Series Ltd.; 2013. p. 103-20.

5. Hansen EA, Emanuelsen A, Gertsen RM, Sørensen SS. Improved marathon performance by in-race nutritional strategy intervention. Int J Sport Nutr Exerc Metab. 2014;24(6):645-55. https://doi.org/10.1123/ijsnem.2013-0130

PMid:24901444

6. Hottenrott K, Hass E, Kraus M, Neumann G, Steiner M, Knechtle B. A scientific nutrition strategy improves time trial performance by $\approx 6 \%$ when compared with a self-chosen nutrition strategy in trained cyclists: A randomized cross-over study. Appl Physiol Nutr Metab. 2012;37(4):637-45. https://doi. org/10.1139/h2012-028

PMid:22587540

7. Puspaningtyas DE, Sari SP, Afriani Y, Mukarromah N. Education Nutrition is Effective in Increasing The Knowledge of Athletes about Nutrition Balance and Meet Fluid Requirements. J Servant Charity Dharma. 2019;2(2):34.

8. Thasim S, Syam A, Najamuddin U. Effects of Nutrition Education to Changes in Knowledge and Intake of Nutrients in Overnutrition Children at SDN Sudirman I Makassar in 2013. FKM Unhas. 2013;7;1-14.

9. Ramadhanti CA, Adespin DA, Julianti HP. Ratio Use of Counseling Methods with and without Media Leaflet on Mother's Knowledge and Attitude about Growing Toddler. Diponegoro Med J (Journal of Medical Doctor Diponegoro). 2019;8(1):99-120.
10. Sulistyo Andarmoyo (Dosen FIK Universitas Muhammadiyah Ponorogo). Ponorogo.pdf. Vol. 1. Pemberian Pendidikan Kesehatan Melalui Media Leafleat Efektif dalam Peningkatan Pengetahuan Perilaku Pencegahan Tuberculosis Paru di Kabupaten Ponorogo; 2015.

11. Dagan N, Beskin D, Brezis M, Reis BY. Effects of social network exposure on nutritional learning: Development of an online educational platform. JMIR Serious Games. 2015;3(2):e7. https://doi.org/10.2196/games.4002

PMid:26441466

12. Rachmawati MN. The effect of providing nutrition education on the knowledge of nutrition and healthy life attitude of adolescents at the Senior High School 2 Sidoarjo. J Cullinary Art. 2014;3: 31-35.

13. Folasire OF, Akomolafe AA, Sanusi RA. Does nutrition knowledge and practice of athletes translate to enhanced athletic performance? Cross-sectional study amongst Nigerian undergraduate athletes. Glob J Health Sci. 2015;7(5):215-25. https://doi.org/10.5539/gjhs.v7n5p215 PMid:26156896

14. Fahri A, Sukmawati S, Nurhasanah N. Effect of Nutrition Education on Nutrition Knowledge and Intake of Energy, Protein and Iron in Adolescents. Medical Health Polytechnic Makassar. 2018;13(1):39.

15. Ozdoğan $Y$, Ozcelik AO. Evaluation of the nutrition knowledge of sports department students of universities. J Int Soc Sports Nutr. 2011;8:11. https://doi.org/10.1186/1550-2783-8-11 PMid:21892942

16. Jessri $M$, Jessri $M$, RashidKhani B, Zinn C. Evaluation of Iranian college athletes' sport nutrition knowledge. Int J Sport Nutr Exerc Metab. 2010;20(3):257-63. https://doi.org/10.1123/ ijsnem.20.3.257 PMid:20601743

17. Torres-McGehee TM, Pritchett KL, Zippel D, Minton DM, Cellamare A, Sibilia M. Sports nutrition knowledge among collegiate athletes, coaches, athletic trainers, and strength and conditioning specialists. J Athl Train. 2012;47(2):205-11. https:// doi.org/10.4085/1062-6050-47.2.205

PMid:22488287 